\title{
PENGARUH ORIENTASI PASAR TERHADAP KINERJA USAHA DI SENTRA PRODUKSI IKAN HIAS AIR TAWAR JAWA BARAT
}

\author{
THE MARKET ORIENTATION EFFECT ON BUSINESS PERFORMANCE \\ OF FRESH WATER ORNAMENTAL FISH PRODUCTION CENTER IN WEST JAVA
}

\author{
Popong Nurhayati*), ${ }^{*}$ Yosini Deliana ${ }^{* *}$, Tuhpawana Priatna Sendjaja ${ }^{* *}$, dan Rita Nurmalina***) \\ *) Sekolah Bisnis, IPB University \\ Jl. Raya Pajajaran, Bogor 16151 \\ ${ }^{* *}$ Jurusan Sosial Ekonomi Pertanian, Fakultas Pertanian, Universitas Padjadjaran \\ Jl. Raya Bandung Sumedang KM 21 Jatinangor, Sumedang 45363 \\ ${ }^{* * *)}$ Departemen Agribisnis, Fakultas Ekonomi dan Manajemen, IPB University \\ Jl. Agatis Kampus IPB Dramaga, Bogor 16680
}

\begin{abstract}
This research aimed to: (1) measure the level of market orientation of freshwater ornamental fish cultivators in West Java production centers, (2) analyze turnover and profits as an indicator of the performance of freshwater ornamental fish aquaculture business in West Java production centers, and (3) analyze the effect of market orientation of fish cultivators on the performance of freshwater ornamental fish aquaculture business in West Java production centers. Primary data were collected through observation and interviews with 240 samples of freshwater ornamental fish cultivators in West Java production centers. Research samples determined by multistage sampling methods. The descriptive analysis and profit and loss analysis were employed to analyze the collected data. Research hypotheses were tested by Spearman correlation. The results showed that the market orientation level of ornamental fish cultivators in West Java production centers was categorized as high. Thus, data mode showed that in 2018 the business made a turnover of Rp216,000,000 and a profit of Rp33,971,333. Market orientation and each of market orientation indicators (market knowledge, consumer orientation, competitor orientation, coordination with labor, and marketing implementation) had a significant and positive relationship to business performance. Consumer orientation was the highest market orientation indicator in the relationship between market orientation and business performance..
\end{abstract}

Keywords: freshwater ornamental fish aquaculture, market orientation, business performance

\begin{abstract}
Abstrak: Penelitian bertujuan (1) Mengukur tingkat orietasi pasar pembudidaya ikan hias air tawar di sentra produksi Jawa Barat, (2) Menganalisis omset dan keuntungan sebagai indikator kinerja usaha budidaya ikan hias air tawar di sentra produksi Jawa Barat, dan (3) Menganalisis pengaruh orietasi pasar pembudidaya ikan terhadap kinerja usaha budidaya ikan hias air tawar di sentra produksi Jawa Barat. Data primer dikumpulkan melalui observasi dan wawancara kepada 240 sampel pembudidaya ikan hias air tawar di sentra produksi Jawa Barat. Penentuan sample penelitian menggunakan multistage sampling. Metode analisis berupa analisis deskriptif dan analisis rugi laba. Pengujian terhadap hipotesis penelitian dilakukan menggunakan korelasi Spearman. Hasil penelitian menunjukkan bahwa tingkat orientasi pasar pembudidaya ikan hias di sentra produksi Jawa Barat terkategori tinggi, sehingga pada tahun 2018 mampu menghasilkan modus omset usaha Rp216 juta dan modus keuntungan usaha Rp33.971.333. Orientasi pasar dan masing-masing indikator orientasi pasar (pengetahuan pasar, orientasi konsumen, orientasi pesaing, koordinasi dengan tenaga kerja dan pelaksanaan pemasaran) memiliki hubungan yang signifikan dan positif terhadap kinerja usaha. Orientasi konsumen merupakan indikator orientasi pasar yang tertinggi dalam hubungan antara orientasi pasar dengan kinerja usaha.
\end{abstract}

Kata kunci: budi daya ikan hias air tawar, orientasi pasar, kinerja usaha

\footnotetext{
${ }^{1}$ Corresponding author:

Email: popongnurhayati14@gmail.com
} 


\section{PENDAHULUAN}

Ikan hias air tawar adalah salah satu komoditas perikanan yang memiliki nilai ekonomi. Kementerian Kelautan dan Perikanan (2014) telah menetapkan lima provinsi di Indonesia sebagai target sentra produksi terbesar ikan hias air tawar, yaitu Jawa Timur, Jawa Barat, DKI Jakarta, D.I. Yogyakarta dan Banten. Kota Depok dan Kabupaten Bogor merupakan dua sentra utama budi daya ikan hias air tawar di Provinsi Jawa Barat. Kota Depok memiliki sepuluh kecamatan dari sebelas kecamatan di kota tersebut yang masyarakatnya melakukan usaha budi daya ikan hias air tawar. Produksi ikan hias air tawar di Kota Depok dari tahun 2012-2015 mengalami peningkatan pertumbuhan ratarata sebesar 6,99\%. Perkembangan usaha ikan hias air tawar tahun 2012-2015 di Kota Depok disajikan pada Tabel 1.

Pemerintah Kabupaten Bogor telah menetapkan sektor perikanan menjadi salah satu indikator pencapaian visi Kabupaten Bogor sebagai kabupaten termaju di Indonesia. Dalam Rencana Pembangunan Jangka Menengah Daerah (RPJMD) tahun 2013-2018, sektor perikanan menjadi salah satu penciri dari 25 penciri lainnya, yaitu penyedia benih ikan konsumsi dan ikan hias terbanyak di Indonesia. Rata-rata jumlah produksi ikan hias air tawar antara tahun 2011-2015 di Kabupaten Bogor mengalami pertumbuhan positif $11,83 \%$, dengan produktivitas rata-rata 369.380 ekor/ pembudi daya/ tahun, seperti ditunjukkan pada Tabel 2.

Usaha budi daya ikan hias air tawar memerlukan input produksi serta berhadapan dengan sejumlah tantangan seperti kondisi cuaca dan iklim yang memungkinkan terjadinya risiko produksi yang terkait dengan penyakit ikan dan tingkat ketahanan hidup (survival rate) ikan. Tantangan lainnya adalah kondisi pasar global yang penuh dengan persaingan serta adanya kesepakatan internasional yang menyangkut lingkungan (limbah produksi) dan jenis-jenis ikan yang dilindungi dalam PP No.7 Tahun 1999 tentang Pengawetan Jenis Tumbuhan dan Satwa atau yang termasuk dalam Appendiks I CITES (Convention on International Trade in Endangered Species), seperti ikan Arwana (Scleropages formosus) dan Arwana Irian (Scleropages jardini), ikan Napoleon, Kuda laut dan karang/koral.

Tabel 1. Perkembangan usaha ikan hias air tawar di Kota Depok tahun 2012-2015

\begin{tabular}{|c|c|c|c|c|c|}
\hline \multirow{2}{*}{ Tahun } & \multirow{2}{*}{$\begin{array}{l}\text { Pembudidaya } \\
\text { (orang) }\end{array}$} & \multicolumn{2}{|c|}{ Produksi } & \multirow{2}{*}{ Nilai Produksi (Rp) } & \multirow{2}{*}{$\begin{array}{l}\text { Produktivitas (Ekor/ } \\
\text { pembudidaya/tahun) }\end{array}$} \\
\hline & & Jumlah (Ekor) & Pertumbuhan $(\%)$ & & \\
\hline 2012 & 377 & 188.936 .640 & - & 25.520 .128 .664 & 503.811 \\
\hline 2013 & 435 & 224.056 .000 & 10,79 & 29.925 .105 .158 & 515.071 \\
\hline 2014 & 435 & 235.173 .740 & 9,03 & 32.363 .238 .814 & 540.629 \\
\hline 2015 & 435 & 242.520 .230 & 1,15 & 32.733 .090 .749 & 557.518 \\
\hline Rataan & 421 & 209.461 .090 & 6,99 & 30.135 .390 .846 & 529.257 \\
\hline
\end{tabular}

Sumber: BPS Kota Depok Tahun 2013, 2014, 2015 dan 2016

Tabel 2. Perkembangan keragaan usaha ikan hias air tawar di Kabupaten Bogor tahun 2011-2015

\begin{tabular}{cccccc}
\hline \multirow{2}{*}{ Tahun } & \multirow{2}{*}{$\begin{array}{c}\text { Pembudidaya } \\
\text { (orang) }\end{array}$} & $\begin{array}{c}\text { Luas Area } \\
(\text { Ha) }\end{array}$ & \multicolumn{2}{c}{ Produksi } & \multirow{2}{*}{ Nilai Produksi (Rp) } \\
\cline { 4 - 5 } & 468 & 33,09 & 156.618 .830 & - & 334.660 \\
2011 & 580 & 35,06 & 188.936 .640 & 20,63 & 325.750 \\
2012 & 580 & 35,06 & 224.056 .000 & 18,59 & 386.300 \\
2013 & 587 & 35,12 & 235.173 .740 & 4,96 & 400.640 \\
2015 & 607 & 35,62 & 242.520 .230 & 3,12 & 399.540 \\
Rataan & 564 & 34,79 & 209.461 .090 & 11,83 & 369.380 \\
\hline
\end{tabular}

Sumber: Disnakkan Kabupaten Bogor (2016) 
Meskipun menghadapi tantangan, usaha budi daya ikan hias air tawar di dua sentra produksi di Jawa Barat mengalami perkembangan jumlah pembudi daya ikan, produksi, nilai produksi dan produktivitas usaha seperti tertera pada Tabel 1 dan Tabel 2. Produk ikan hias air tawar juga dapat dipasarkan secara lokal dan menembus pasar ekspor. Namun demikian, belum diketahui sejauh mana orientasi pasar pembudi daya ikan hias air tawar di Jawa Barat dalam menjalankan usahanya dan pengaruhnya terhadap kinerja usahanya. Berdasarkan perkembangan usaha yang terjadi di sentra produksi Jawa Barat, penulis menduga bahwa orientasi pasar pembudi daya ikan hias berpengaruh signifikan terhadap kinerja usaha budi daya ikan hias air tawar.

Penelitian ini menggunakan penelitian terdahulu sebagai acuan. Persamaan penelitian ini dengan penelitian sebelumnya adalah mengenai topik orientasi pasar dan kinerja usaha. Pada penelitian ini digunakan indikatorindikator orientasi pasar yang merupakan gabungan dari penelitian terdahulu (Han et al. (1998); Halim et al. (2012); Gholami dan Birjandi (2016); Riana (2010); Umar (2014); Narver dan Slater (1993); serta Hartelina, (2010)), yaitu orientasi konsumen dan orientasi pesaing, dan koordinasi antar fungsi, pengetahuan pasar dan orientasi pelaksanaan pemasaran. Umumnya usaha budi daya ikan hias belum berbentuk lembaga usaha melainkan masih berupa usaha rumah tangga, sehingga koordinasi antar fungsi dalam penelitian ini diganti menjadi koordinasi dengan tenaga kerja. Perbedaan dengan penelitian terdahulu terutama pada objek penelitian dan komponen (item) pernyataan yang diajukan kepada responden pada kelima indikator orientasi pasar yang disesuaikan dengan fakta yang terjadi pada usaha budi daya ikan hias air tawar pada skala usaha rumah tangga.

Usaha budi daya ikan hias air tawar di Jawa Barat umumnya masih berskala kecil atau skala rumah tangga, sehingga dikenal istilah rumah tangga perikanan. Ikan hias air tawar merupakan hasil perikanan nonkonsumsi, sehingga meskipun tergolong usaha kecil, seluruh hasil produksinya ditujukan untuk memenuhi kebutuhan pasar, baik pasar lokal maupun pasar ekspor.

Ikan hias air tawar asal Kabupaten Bogor selain dipasarkan secara lokal juga telah menembus pasar ekspor melalui distribusi ke beberapa negara oleh sejumlah eksportir. Ikan hias air tawar asal Kabupaten
Bogor dipasarkan ke 10 negara tujuan ekspor, yaitu Jepang (14,02\%), Jerman (13,90\%), Iran (13,08\%), Belanda (9,46\%), Saudi Arabia (8,82\%), Thailand $(6,60 \%)$, Switzerland $(6,33 \%)$, Republic of Korea (5,31\%), Greece (3,48\%), dan Spanyol (2,14\%). Sebagian eksporikanhias airtawarasalKabupaten Bogor dilakukan melalui Singapura (Diskopukmperindag Kabupaten Bogor, 2015). Sedangkan ikan hias air tawar asal Kota Depok telah dipasarkan antara lain ke beberapa negara Eropa, Amerika dan Singapura.

Aliran produk ikan hias air tawar dari pembudi daya ikan ke pasar lokal maupun pasar ekspor melalui pedagang pengumpul lokal, pedagang besar dan eksportir dalam perdagangan ikan hias air tawar diduga karena pembudi daya ikan memiliki orientasi pasar. Ruekert (1992) menggambarkan orientasi pasar sebagai tingkat di mana unit bisnis: (1) memperoleh dan menggunakan informasi dari pelanggan; (2) mengembangkan suatu strategi yang akan menemukan kebutuhan pelanggan; dan (3) mengimplementasikan strategi dengan mendengarkan kebutuhan dan kekurangan pelanggan. Para peneliti mengembangkan teori orientasi pasar dilandasi oleh konsep pemasaran. Kohli et al. (1993) menunjukkan bahwa konsep pemasaran merupakan filosofi bisnis, sedangkan orientasi pasar menunjukkan implementasi dari konsep tersebut dalam organisasi. Narver dan Slatter (1990) berpendapat bahwa untuk bisnis komoditas dan nonkomoditas, orientasi pasar merupakan faktor penting dalam menentukan tingkat keuntungan perusahaan.

Saeed dan Aimin (2015) menyatakan perusahaan yang memiliki orientasi pasar yang kuat dapat mendeteksi kebutuhan konsumen sebelum pasar secara umum menyadarinya. Dengan demikian perusahaan seperti ini merupakan inovator yang mencoba memberi apa yang diinginkan pelanggan lebih cepat dari pesaing. Orientasi pasar berarti perusahaan beroperasi dengan pendekatan utama kepada pasar atau pelanggan. Perusahaan yang memiliki orientasi pasar berarti mempertemukan kebutuhan atau keinginan pelanggan sasarannya sebagai motivasi utama dalam bisnisnya diantaranya melalui: (1) Pengembangan produk baru; (2) Memperbaiki produk yang ada; atau (3) Meningkatkan pelayanan. Terkait orientasi pasar tersebut, maka permasalahan yang dapat dirumuskan adalah seberapa besar tingkat orientasi pasar pembudi daya ikan hias air tawar dalam menjalankan usahanya?. 
Bisnis ikan hias air tawar sangat terkait dengan preferensi konsumen dalam hal fungsi (alasan memelihara ikan hias), jenis, bentuk, ukuran, warna, dan perilaku ikan hias yang berbeda-beda. Untuk melayani kebutuhan dan keinginan pasar lokal maupun pasar ekspor serta mengelola risiko usahanya maka pembudiaya ikan melakukan strategi penyediaan beberapa jenis, ukuran dan warna ikan hias air tawar dalam usaha budi dayanya. Seiring perkembangan usaha pembesaran ikan hias air tawar di Jawa Barat, kegiatan usaha budi daya ikan hias pun tersegmentasi menjadi usaha pembesaran dan pembenihan. Oleh karena itu, terdapat peluang pasar yang bersumber dari kebutuhan benih ikan hias untuk pengembangan usaha pembesaran ikan hias, yang mendorong sebagian pembudi daya pembesaran ikan hias untuk melakukan diversifikasi usaha berupa pembenihan ikan hias air tawar. Tujuan penelitian ini adalah (1) mengukur tingkat orietasi pasar pembudi daya ikan hias air tawar di sentra produksi Jawa Barat, (2) menganalisis omzet dan keuntungan sebagai indikator kinerja usaha budi daya ikan hias air tawar di sentra produksi Jawa Barat, dan (3) menganalisis pengaruh orietasi pasar pembudi daya ikan terhadap kinerja usaha budi daya ikan hias air tawar di sentra produksi Jawa Barat.

\section{METODE PENELITIAN}

Data yang digunakan berupa data primer dan data sekunder. Metode pengumpulan data dilakukan dengan metode survei. Data primer dikumpulkan melalui observasi dan wawancara lansung kepada responden (pembudi daya ikan) dengan berpedoman pada kuesioner. Untuk kelengkapan data dilakukan wawancara kepada responden pendukung seperti ketua kelompok pembudi daya ikan (pokdakan), pengurus koperasi ikan hias, pedagang pengumpul dan penyuluh perikanan. Data sekunder dikumpulkan melalui studi literatur dari text book, jurnal-jurnal ilmiah, hasil-hasil penelitian ilmiah dan dokumentasi beberapa instansi terkait.

Populasi penelitian berada di Kota Depok dan Kabupaten Bogor yang merupakan sentra produksi ikan hias air tawar di Jawa Barat. Sampel penelitian berjumlah 240 pembudi daya ikan hias air tawar, seperti terlihat pada Tabel 3. Penentuan sampel dilakukan dengan beberapa langkah (multistage sampling), yaitu memilih dengan sengaja kecamatan yang merupakan sentra terbesar budi daya ikan hias air tawar di Kota Depok dan Kabupaten Bogor, kemudian menentukan jumlah responden dengan menggunakan teknik proportional cluster sampling berdasarkan banyaknya pembudi daya ikan di kecamatan-kecamatan terpilih. Untuk keseimbangan jumlah samplel di dua lokasi sentra produksi, dilakukan penambahan sampel di Kabupaten Bogor sebanyak 52 sampel yang pengalokasiannya dihitung secara proporsional pada kecamatan terplih. Jumlah sampel pembudi daya ikan di Kota Depok 119 orang dan dan jumlah sampel di Kabupaten Bogor 121 orang, sehingga total sampel menjadi 240 orang pembudi daya ikan.

Tingkat orientasi pasar diperoleh melalui perhitungan skor. Indikator orientasi pasar yang digunakan terdiri dari 1) Pengetahuan pasar, 2) Orientasi konsumen, 3) Orientasi pesaing, 4) Koordinasi dengan tenaga kerja, dan 5) Orientasi pelaksanaan pemasaran, yang diperoleh berdasarkan penggabungan dari kajian terdahulu (Narver dan Slatter, 1990; Kohli et al. 1993; Saeed dan Aimin, 2015). Masing-masing indikator orientasi pasar memiliki jumlah komponen (item) pernyataan yang berbeda. Total komponen pernyataan untuk kelima indikator orientasi pasar adalah 23. Setiap komponen pernyataan diberi skor lima, dengan kategori: $5=\mathrm{SS}$ (sangat setuju); $4=\mathrm{S}$ (setuju); $3=\mathrm{TT}$ (netral/tidak tahu; $2=\mathrm{TS}$ (tidak setuju); dan 1=STS (sangat tidak setuju). Klasifikasi tingkatan untuk setiap komponen pernyataan dari kelima indikator diperoleh berdasarkan pengurangan skala tertinggi dengan skala terendah kemudian hasilnya dibagi 5 kategori. Dengan demikian diperoleh lima interval kelas, yaitu $1,0 \leq$ sangat rendah $<1,8 ; 1,8 \leq$ rendah $<2,6 ; 2,6 \leq$ sedang $<$ 3,$4 ; 3,4 \leq$ tinggi $<4,2 ; 4,2 \leq$ sangat tinggi $<5$.

Tingkatan masing-masing indikator orientasi pasar diperoleh berdasarkan nilai rataan skor setiap komponen pernyataan dari indikator bersangkutan pada interval kelasnya. Komponen pernyataan dengan nilai rataan skor tertinggi merupakan prioritas untuk dideskripsikan. Pada setiap komponen pernyataan dihitung jumlah persentase jawaban responden yang memberikan skor jawaban $5=\mathrm{SS}$ (sangat setuju) dan $4=\mathrm{S}$ (setuju) sebagai nilai persentase tertinggi dari komponen pernyataan tersebut. 
Tabel 3. Jumlah populasi dan sampel berdasarkan lokasi penelitian

\begin{tabular}{llccccc}
\hline Lokasi & Kecamatan & $\begin{array}{c}\text { Populasi } \\
\text { Pembudidaya } \\
\text { ikan (orang) }\end{array}$ & $\begin{array}{c}\text { Proporsi } \\
(\%)\end{array}$ & $\begin{array}{c}\text { Sampel } \\
\text { Pembudidaya } \\
\text { ikan (orang) }\end{array}$ & $\begin{array}{c}\text { Penambahan } \\
\text { Sampel } \\
\text { pembudidaya (orang) }\end{array}$ & $\begin{array}{c}\text { Total Sampel } \\
\text { Pembudidaya } \\
\text { ikan (orang) }\end{array}$ \\
\hline Kota & Bojongsari & 184 & 0,58 & 107 & - & 107 \\
Depok* & Cipayung & 22 & 0,07 & 2 & - & 2 \\
& Sukmajaya & 27 & 0,09 & 2 & - & 2 \\
& Cilodong & 24 & 0,08 & 2 & - & 2 \\
& Tapos & 41 & 0,13 & 5 & - & 5 \\
& Pancoran Mas & 18 & 0,06 & 1 & - & 1 \\
Kabupaten & Jumlah & 316 & 1,00 & 119 & 7 & 119 \\
Bogor** & Ciampea & 60 & 0,13 & 8 & 5 & 10 \\
& Kemang & 46 & 0,10 & 5 & 9 & 22 \\
& Parung & 77 & 0,17 & 13 & 11 & 30 \\
& Ciseeng & 93 & 0,21 & 19 & 9 & 22 \\
& Cibinong & 75 & 0,17 & 13 & 4 & 16 \\
& Gunung Sindur & 35 & 0,08 & 3 & 7 & 121 \\
& Tenjolaya & 62 & 0,14 & 9 & 52 & 240 \\
\hline & Jumlah & 448 & 1,00 & 69 & & 7 \\
& Total & 764 & & & & \\
\hline
\end{tabular}

Sumber: * Dinas TPPP Kota Depok (2016); ** DISNAKKAN Kabupaten Bogor (2016)

Pengolahan data tingkat keuntungan dan omzet usaha budi daya ikan hias air tawar menggunakan analisis usahatani dengan rumus matematika:

$$
\begin{gathered}
\pi=\mathrm{TR}-\mathrm{TC} \\
\mathrm{TR}=\mathrm{P} \quad \mathrm{X} \mathrm{Q} \\
\mathrm{TC}=\mathrm{TFC}+\mathrm{TVC}
\end{gathered}
$$

Keterangan: $\pi$ (Keuntungan bersih (Rp)); TR (Total penerimaan atau omzet (Rp)); P (Harga ikan hias (Rp/ ekor)); Q (Jumlah produksi ikan hias (ekor)); TC (Total biaya (Rp)); TFC (Total biaya tetap (Rp)); TVC (Total biaya variabel $(\mathrm{Rp}))$.

Tipe data orientasi pasar adalah data ordinal, sedangkan dengan indikator kinerja usaha (omzet dan keuntungan usaha) menggunakan data nominal. Oleh karena itu, hubungan antara orientasi pasar dengan kinerja usaha diolah menggunakan statistik nonparametrik berupa korelasi Spearman, dengan aplikasi SPSS versi 20. Rumus korelasi Spearman adalah sebagai berikut:

$$
r_{s}=1-\frac{6 \sum d i^{2}}{n\left(n^{2}-1\right)}
$$

Keterangan: rs (nilai korelasi rank sprearman); 6 (konstanta); di (selisih ranking); n (jumlah sampel).
Peneliti terdahulu (Umar, 2014) menemukan hubungan positif dan signifikan antara orientasi pasar dengan pertumbuhan penjualan (omzet) sebagai salah satu indikator kinerja usaha. Demikian pula, Hartelina (2010) menemukan hubungan postif dan signifikan antara orientasi pasar dengan keuntungan usaha. Pada penelitian ini diduga terdapathubungan signifikan antara orientasi pasar dengan kinerja usaha. Berdasarkan latar belakang, perumusan masalah dan tujuan penelitian, kerangka pemikiran penelitian ini ditunjukkan pada Gambar 1. Selanjutnya, hipotesis penelitian secara keseluruhan adalah sebagai berikut:

Hipotesis 1 (H1): Ho1: Tidak terdapat hubungan yang signifikan antara orientasi pasar dengan omzet usaha; Ha1: Terdapat hubungan yang signifikan antara orientasi pasar dengan omzet usaha

Hipotesis 2 (H2): Ho2: Tidak terdapat hubungan yang signifikan antara orientasi pasar dengan keuntungan usaha; Ha2: Terdapat hubungan yang signifikan antara orientasi pasar dengan keuntungan usaha

Hipotesis 3 (H3): Ho3: Tidak terdapat hubungan yang signifikan antara indikator-indikator orientasi pasar (pengetahuan pasar, orientasi konsumen, orientasi pesaing, koordinasi dengan tenaga kerja dan pelaksanaan pemasaran) dengan omzet usaha; 
Ha3: Terdapat hubungan yang signifikan antara indikator-indikator orientasi pasar (pengetahuan pasar, orientasi konsumen, orientasi pesaing, koordinasi dengan tenaga kerja dan pelaksanaan pemasaran) dengan omzet usaha

Hipotesis 4 (H4): Ho4: Tidak terdapat hubungan yang signifikan antara indikator-indikator orientasi pasar (pengetahuan pasar, orientasi konsumen, orientasi pesaing, koordinasi dengantenaga kerja dan pelaksanaan pemasaran) dengan keuntungan usaha; Ha4: Terdapat hubungan yang signifikan antara indikator-indikator orientasi pasar (pengetahuan pasar, orientasi konsumen, orientasi pesaing, koordinasi dengan tenaga kerja dan pelaksanaan pemasaran) dengan keuntungan usaha.

\section{HASIL}

\section{Karakteristik Responden dan Kegiatan Usahanya}

Mayoritas responden (Tabel 4) adalah laki-laki (96,67\%) sedangkan perempuan hanya 3,33\%; hal ini terkait dengan sifat usaha budi daya ikan sebagai mata pencaharian utama yang umumnya dilakukan oleh kaum laki-laki sebagai kepala keluarga. Proporsi terbesar kelompok usia responden berada pada rentang usia produktif (30-39 tahun dan 40-49 tahun (total $67,92 \%$ ) merupakan hal positif yang diharapkan dapat mencapai kinerja usaha yang tinggi. Mayoritas tingkat pendidikan formal responden adalah tamat Sekolah Menengah Atas (37,08\%); merupakan potensi yang baik untuk pengembangan kemampuan sumberdaya manusia dalam bisnis ikan hias.

Proporsi terbesar responden telah menjalankan usaha antara 6-10 tahun $(36,25 \%)$ diikuti oleh pengalaman usaha antara 11-15 tahun (22,92\%) menunjukkan bahwa usaha memiliki potensi kalangsungan untuk jangka panjang mayoritas responden memiliki jumlah tanggungan keluarga 3-4 orang $(52,50 \%)$ yang menunjukkan bahwa usaha budi daya ikan hias air tawar mampu menghidupi keluarga atau berpotensi meningkatkan kesejahteraan keluarga.

Ikan hias air tawar yang diproduksi oleh responden pembudi daya ikan ada 87 spesies dengan ukuran dan harga yang bervariasi tergantung pada lama pemeliharaan, disesuaikan dengan pesanan pembeli dan sebagai antisipasi terhadap selera pasar. Volume produksi, biaya variabel dan biaya tetap serta keuntungan usaha budi daya ikan hias bervariasi sesuai dengan kapasitas produksi, harga input produksi dan harga jual ikan hias.

Usaha budi daya ikan hias air tawar merupakan usaha utama dari $88,75 \%$ responden di Jawa Barat. Dengan demikian usaha ini merupakan usaha untuk memenuhi kebutuhan hidup dan meningkatkan kesejahteraan keluarga pembudi daya ikan. Hal ini mengindikasikan pentingnya pembudi daya ikan mengelola usaha dengan lebih baik (profesional) agar produktivitas usaha tersebut lebih tinggi sehingga lebih menguntungkan, bertahan dalam jangka panjang (sustain) dan semakin mendukung peningkatan kesejahteraan keluarga.

Proporsi terbesar $(64,17 \%)$ responden pembudi daya ikan melakukan diversifikasi usaha pembesaran sekaligus pembenihan, sedangkan $35,00 \%$ pembudi daya ikan berspesialisasi pada usaha pembesaran. Media proses budi daya ikan berupa akuarium digunakan oleh $47,08 \%$ responden, sedangkan $32,92 \%$ responden menggunakan kolam sebagai media budi daya, dan $20,00 \%$ menggunakan campuran akuarium, kolam dan berbagai wadah lain (kantong plastik, ember plastik dan lain-lain) yang biasanya dilakukan oleh pembudi daya ikan Cupang.

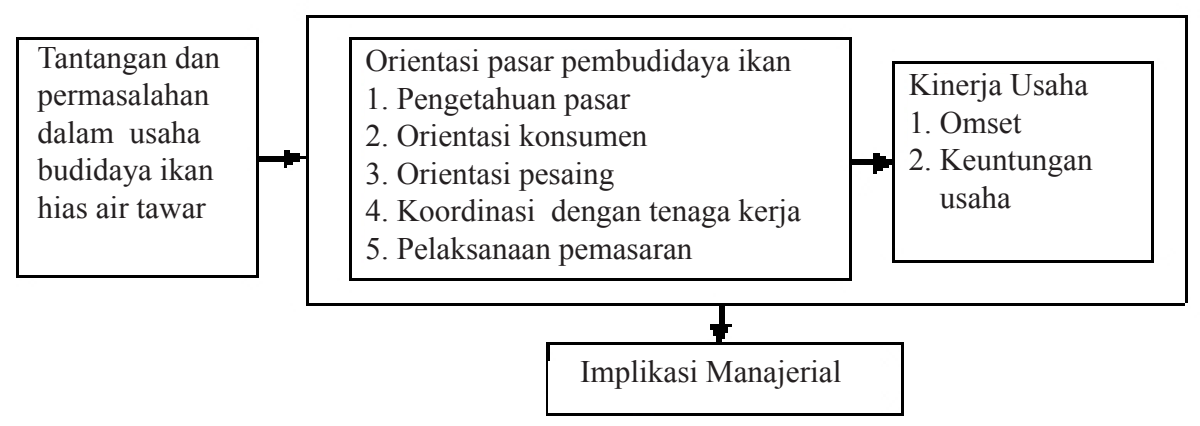

Gambar 1. Kerangka pemikiran 
Tabel 4. Karakteristik responden pembudidaya ikan hias air tawar di sentra produksi Jawa Barat $(n=240)$

\begin{tabular}{lc}
\hline Karakteristik & $(\%)$ \\
\hline Jenis kelamin & \\
Laki-laki & 96,67 \\
Perempuan & 3,33 \\
Umur (Tahun) & \\
$>=60$ & 5,42 \\
$50-59$ & 12,92 \\
$40-49$ & 30,42 \\
$30-39$ & 37,50 \\
$18-29$ & 13,75 \\
Pendidikan formal & \\
SD & 31,67 \\
SMP & 27,50 \\
SMA & 37,08 \\
Diploma/Sarjana & 3,33 \\
Pasca Sarjana & 0,42 \\
Sifat usaha & \\
Utama & \\
Sampingan & 88,75 \\
Pengalaman berusaha (Tahun) & 11,25 \\
$1-5$ & \\
$6-10$ & 20,83 \\
$11-15$ & 36,25 \\
$16-20$ & 22,92 \\
$>20$ & 14,58 \\
Tanggungan keluarga (Orang) & 5,42 \\
$<1$ & \\
1 - 2 & 5,83 \\
$3-4$ & 25,83 \\
$5-6$ & 52,50 \\
$>$ & 13,33 \\
\hline & 2,50 \\
\hline
\end{tabular}

\section{Tingkat Orientasi Pasar}

Tabel 5 menunjukkan bahwa tingkat orientasi pasar pembudi daya ikan hias air tawar di sentra produksi Jawa Barat terkategori tinggi (rataan skor 3,69). Hal ini didukung oleh rataan skor seluruh indikator orientasi pasar dengan kategori tinggi. Indikator orientasi pasar tertinggi dari kelima indikator orientasi pasar adalah orientasi konsumen, khususnya dalam hal menjalankan komitmen (memenuhi janji kepada konsumen). Diantara bentuk orientasi kepada konsumen adalah memberikan pelayanan yang terbaik yang sesuai dengan harapan konsumen sehingga mereka merasa puas, sejalan dengan hasil penelitian Mutamman et al. (2019), agar kinerja usaha terus meningkat karena pembudi daya ikan menghadapi perilaku pasar ekspor ikan hias air tawar dengan tingkat persaingan semakin ketat dan ketidak pastian semakin tinggi.

\section{Pengetahuan Pasar}

Tingkat pengetahuan pasar pembdidaya ikan terkategori tinggi karena didukung oleh emmpat komponen pengetahuan pasar yang memiliki kategori tinggi, meliputi: pengetahuan perkembangan produksi di beberapa sentra di Jawa Barat, membaca tren pasar lokal ikan hias, membaca tren pasar ekspor ikan hias dan membaca peluang pasar.

Pengetahuan pasar yang tinggi merupakan hal positif karena memungkinkan pembudi daya ikan untuk melakukan perencanaan pengembangan usaha budi daya ikan hias air tawar yang lebih baik. Komponen tertinggi dari indikator pengetahuan pasar adalah membaca tren pasar ekspor ikan hias. Pembudi daya ikan membaca tren pasar ekspor ikan hias melalui kecenderungan peningkatan permintaan jenisjenis ikan hias dari pembeli (pedagang pengumpul), informasi dari internet dan sesama pembudi daya ikan. Hal ini sangat berguna untuk melakukan strategi pengembangan usaha budi daya ikan hias maupun pengembangan pemasarannya.

Pembudi daya ikan menyatakan bahwa mereka mengetahui perkembangan produksi di beberapa sentra di Jawa Barat seperti Cianjur, Bekasi, Yogyakarta, DKI Jakarta, antara lain terkait jenis ikan hias atau harga beberapa jenis ikan, atau aktivitas produksi pembudi daya. Pengetahuan tersebut diperoleh berdasarkan informasi dari internet, dari sesama pembudi daya ikan, dari acara-acara seminar nasional, bimbingan teknis atau pelatihan yang diselenggarakan oleh kelembagaan pendukung agribisnis seperti Dinas TPP Kota Depok, Balitbangdias Kota Depok, Disnakan Kabupaten Bogor atau Disperdagin Kabupaten Bogor.

\section{Orientasi Konsumen}

Tingkat orientasi konsumen para pembudi daya ikan tergolong tinggi. Tingginya tingkat orientasi konsumen ini didukung oleh komponen-komponen orientasi konsumen yang memiliki kategori tinggi, terdiri dari: tanggapan terhadap keluhan konsumen, menciptakan nilai tambah/keunggulan ikan hias, (berupa keaneka ragaman jenis ikan dan kualitas ikan hias yang baik), memelihara hubungan jangka penjang dengan 
konsumen utama, (dalam bentuk komunikasi yang baik), upaya mengetahui kepuasan pelanggan (dengan mengadakan komunikasi pasca pembelian ikan oleh konsumen).

Komponen tertinggi orientasi konsumen adalah menjalankan komitmen (memenuhi janji ke konsumen). Hal ini dilakukan poleh pembudi daya ikan dalam bentuk pemenuhan permintaan ikan hias yang tepat jenis, tepat ukuran, tepat jumlah dan tepat waktu. Kemampuan orientasi kepada konsumen dapat memberi implikasi bisnis berupa kemungkinan terjadinya kelangsungan usaha dalam jangka penjang, seperti terbukti dari adanya responden yang telah menjalankan usaha antara 6-10 tahun (36,25\%) dan 1115 tahun $(22,92 \%)$.

\section{Orientasi Pesaing}

Tingkat orientasi pesaing pembudi daya ikan tergolong tinggi. Tingginya tingkat orientasi pesaing ini didukung oleh kelima komponen orientasi pesaing dari pembudi daya ikan yang masing-masing tergolong tinggi yaitu: adanya pemahaman bahwa konsumen dapat beralih ke produsen/pembudi daya lain, menyadari adanya persaingan usaha, berupaya mencari informasi pesaing, memantau strategi pesaing, dan menanggapi strategi pesaing.

Komponen tertinggi orientasi pesaing yaitu pembudi daya ikan memahami bahwa konsumen dapat beralih ke produsen /pembudi daya lain, yang tentunya merupakan pesaing bagi mereka. Sebagai respon atas strategi pesaing, pembudi daya ikan di sentra produksi Jawa Barat menyatakan bahwa mereka mencari informasi bagaimana pembudi daya ikan dari sentra produksi lain melakukan pencarian informasi atau melakukan pelatihan secara mandiri di Balitbangdias
(Balai Penelitian dan Pengembangan Budi daya Ikan Hias) Kota Depok untuk menambah kemampuannya dalam teknologi budi daya ikan hias jenis-jenis tertentu. Pembudi daya ikan di sentra produksi Jawa Barat berupaya menanggapi strategi pesaing dengan cara menyediakan ikan hias yang memenuhi keinginan pelanggan seperti ukuran yang tepat, ikan yang sehat, warna yang terang, dan jenis ikan sesuai pesanan.

\section{Koordinasi dengan Tenaga Kerja}

Tingkat koordinasi dengan tenaga kerja yang dilakukan pembudi daya ikan terkategori tinggi. Hal ini didukung oleh kelima komponen penentu koordinasi dengan tenaga kerja yang terkategori tinggi, yaitu terlibat aktif bersama tenaga kerja, melayani kebutuhan konsumen, memotivasi tenaga kerja untuk melayani konsumen, memantau tenaga kerja dalam pelayanan konsumen, tenaga kerja boleh ikut serta mencari konsumen, dan dominansi pembudi daya ikan dalam melayani kebutuhan konsumen.

Komponen tertinggi pada koordinasi dengan tenaga kerja adalah memotivasi tenaga kerja untuk melayani konsumen dengan baik. Hal ini merupakan hal yang positif dalam rangka menjaga kepercayaan pembeli dan kelangsungan usaha yang mereka kelola. Dalam koordinasi dengan tenaga kerja, pembudi daya ikan yang memiliki tenaga kerja dari luar keluarga (TKLK) mengelola tenaga kerja mulai dari proses rekrutmen maupun dalam proses produksi ikan hias secara rutin. Pembudi daya ikan yang menggunakan tenaga kerja dari dalam keluarga (TKDK) melakukan komunikasi secara rutin dan pendekatan kekeluargaan agar tenaga kerja tersebut memahami tugas atau fungsinya dalam membantu kegiatan usaha budi daya ikan hias sebagai usaha rumah tangga.

Tabel 5. Kategori dan persentase komponen tertinggi dari orientasi pasar

\begin{tabular}{|c|c|c|c|c|}
\hline Indikator orientasi pasar & Rataan skor & Kategori* & $\%$ Tertinggi & Komponen pernyataan \\
\hline Pengetahuan pasar & 3,59 & Tinggi & 60,83 & Membaca tren pasar ekspor ikan hias \\
\hline Orientasi konsumen & 3,98 & Tinggi & 81,25 & $\begin{array}{l}\text { Menjalankan komitmen (memenuhi janji ke } \\
\text { konsumen) }\end{array}$ \\
\hline Orientasi pesaing & 3,71 & Tinggi & 69,17 & $\begin{array}{l}\text { Memahami bahwa konsumen dapat beralih ke } \\
\text { produsen /pembudidaya lain }\end{array}$ \\
\hline $\begin{array}{l}\text { Koordinasi dengan tenaga } \\
\text { kerja }\end{array}$ & 3,70 & Tinggi & 67,08 & Memotivasi tenaga kerja untuk melayani konsumen \\
\hline $\begin{array}{l}\text { Orientasi pelaksanaan } \\
\text { pemasaran }\end{array}$ & 3,48 & Tinggi & 63,75 & Memenuhi permintaan konsumen yang ada saat ini \\
\hline Rataan keseluruhan & 3,69 & Tinggi & & \\
\hline
\end{tabular}




\section{Orientasi Pelaksanaan Pemasaran}

Tingkat orientasi pelaksanaan pemasaran para pembudi daya ikan tergolong tinggi karena didukung oleh ketiga komponennya yang masing-masing memiliki kategori tinggi, yakni memprediksi kebutuhan konsumen, memenuhi permintaan konsumen yang ada saat ini, dan melakukan penawaran kepada calon konsumen baru. Komponen tertinggi orientasi pelaksanaan pemasaran adalah memenuhi permintaan konsumen saat ini, hal ini berarti secara ril belum berorientasi kepada konsumen atau wilayah pasar yang baru. Namun demikian pembudi daya ikan menyatakan bahwa mereka melakukan penawaran ikan hias baru (yang tidak biasa mereka produksi) atau jenis tertentu kepada pedagang pengumpul yang telah menjadi pelanggan maupun bukan pelanggan, kepada pedagang pengecer di pasar ikan hias Parung, Kabupaten Bogor atau bursa ikan hias Laladon di Kota Bogor.

Penawaran ikan hias yang dilakukan pembudi daya ikan merupakan penjajagan sebelum mereka benarbenar meyakini adanya permintaan ikan hias baru atau jenis tertentu, karena sebagian dari pembudi daya pada saat ini memiliki keterbatasan modal usaha. Hal ini mengindikasikan perlunya dukungan modal yang lebih besar dari kelembagaan pendukung agribisnis (perbankan, perusahaan swasta melalui program CSR, pemerintah melalui program PUMP (Pengembangan Usaha Mina Pedesaan) atau sejenisnya agar pembudi daya ikan hias air tawar dapat lebih mengembangkan usahanya.

Pembudi daya ikan memprediksi kebutuhan pasar berdasarkan rata-rata jumlah permintaan ikan hias yang selama ini dilakukan oleh pelanggannya, karena informasi yang lebih detail mengenai jumlah kebutuhan ikan hias dari pelanggan belum tersedia secara formal. Hal ini mengindikasikan perlunya dukungan kelembagaan agribisnis terkait untuk melakukan market inteligent dan penyediaan informasi pasar ikan hias (supply dari negara-negara produsen dan demand dari negara-negara tujuan ekspor).

\section{Tingkat Keuntungan dan Omzet Usaha}

Usaha budi daya ikan hias air tawar hingga periode tahun 2018 menghasilkan tingkat Omzet terendah Rp64.575.000 dan tertinggi Rp2.437.890.000 serta modus Omzet Rp216.000.000. Usaha ini juga menguntungkan dengan tingkat keuntungan terendah Rp33.971.333 dan tingkat keuntungan tertinggi Rp1.987.138.290 serta modus keuntungan Rp33.971.333 dengan modus frekuensi (periode) budi daya 6 kali per tahun. Hal ini sejalan dengan penelitian terdahulu (Rani et al. 2014; dan Raja et al. 2014) di salah satu sentra produksi dan pesaing pasar ikan hias Indonesia yaitu India, bahwa usaha budi daya ikan hias air tawar menguntungkan.

Omzet dan keuntungan usaha dapat berubah-ubah dari waktu ke waktu. Namun, hasil penelitian ini menunjukkan, 79 orang $(33,00 \%)$ pembudi daya ikan hias air tawar di sentra produksi Jawa Barat memiliki Omzet di atas rata rata sedangkan 75,83\% pembudi daya ikan dalam selang waktu 3 tahun terakhir menyatakan mengalami kenaikan keuntungan usaha serta $68,75 \%$ pembudi daya ikan menyatakan mengalami penambahan aset. Kemampuan pembudi daya ikan dalam meningkatkan aset usaha dan aset berharga lainnya serta perluasan usaha terkait dengan perolehan keuntungan usaha budi daya ikan hiasnya, karena sebagian keuntungan usaha digunakan untuk peningkatan aset/investasi dan pengembangan uasaha, misalnya diversifikasi usaha berupa pembenihan ikan hias atau aquascape. Rekapitulasi hasil analisis usaha budi daya ikan hias air tawar di sentra produksi Jawa Barat disajikan pada Tabel 6.

\section{Pengaruh Orientasi Pasar terhadap Kinerja Usaha}

Hasil uji hipotesis pertama (Ha1) pada Tabel 7 menunjukkan bahwa hubungan antara orientasi pasar secara keseluruhan dengan Omzet usaha diterma. Artinya orientasi pasar secara keseluruhan memiliki hubungan yang signifikan dengan Omzet usaha pada taraf nyata $10 \%$, dengan nilai rs (rank Spearman) positif. Berarti semakin tinggi orientasi pasar pembudi daya ikan maka Omzet usaha budi daya ikan hias air tawar akan semakin meningkat.

Hasil uji hipotesis kedua (Ha2) juga menunjukkan bahwa hubungan antara orientasi pasar secara keseluruhan dengan keuntungan usaha diterima. Artinya orientasi pasar secara keseluruhan memiliki hubungan yang signifikan dengan keuntungan usaha pada taraf nyata $10 \%$, dengan nilai rs (rank Spearman) positif. Berarti semakin tinggi orientasi pasar pembudi daya ikan maka keuntungan usaha budi daya ikan hias air tawar akan semakin meningkat. 
Tabel 6. Statistik deskriptif keragaan usaha budidaya ikan hias air tawar di sentra produksi Jawa Barat ( $\mathrm{n}=240$ )

\begin{tabular}{lccc}
\hline Komponen Analisis Usaha & Minimum & Maximum & Modus \\
\hline Volume produksi (ekor/tahun) & 12.600 & 5.244 .000 & 60.000 \\
Frekuensi (periode) budidaya per tahun & 3 & 12 & 6 \\
Omset per tahun (Rp) & 64.575 .000 & 2.437 .890 .000 & 216.000 .000 \\
Biaya variabel per tahun (Rp) & 4.868 .000 & 553.440 .000 & 53.580 .000 \\
Biaya tetap per tahun (Rp) & 3.702 .857 & 328.251 .710 & 24.767 .452 \\
Keuntungan per Tahun (Rp) & 33.971 .333 & 1.987 .138 .290 & 33.971 .333 \\
\hline
\end{tabular}

Tabel 7. Hasil uji korelasi Spearman $(n=240)$

\begin{tabular}{lccc}
\hline Hubungan antar variabel & $\begin{array}{c}\text { Koefisien } \\
\text { korelasi }\end{array}$ & $\begin{array}{c}\text { Probabilitas } \\
(\text { Sig. }(2 \text {-tailed })\end{array}$ & $\begin{array}{c}\text { Hasil pengujian } \\
\text { hipotesis }\end{array}$ \\
\hline Orientasi pasar $\rightarrow$ Omzet & $0,512^{* *}$ & 0,000 & Diterima \\
Orientasi pasar $\rightarrow$ Keuntungan usaha & $0,465^{* *}$ & 0,000 & Diterima \\
Pengetahuan pasar $\rightarrow$ Omzet & $0,392^{* *}$ & 0,000 & Diterima \\
Pengetahuan pasar $\rightarrow$ Keuntungan usaha & $0,334^{* *}$ & 0,000 & Diterima \\
Orientasi konsumen $\rightarrow$ Omzet & $0,485^{* *}$ & 0,000 & Diterima \\
Orientasi konsumen $\rightarrow$ Keuntungan usaha & $0,441^{* *}$ & 0,000 & Diterima \\
Orientasi pesaing $\rightarrow$ Omzet & $0,447^{* *}$ & 0,000 & Diterima \\
Orientasi pesaing $\rightarrow$ Keuntungan usaha & $0,407^{* *}$ & 0,000 & Diterima \\
Koordinasi dengan tenaga kerja $\rightarrow$ Omzet & $0,475^{* *}$ & 0,000 & Diterima \\
Koordinasi dengan tenaga kerja $\rightarrow$ Keuntungan usaha & $0,433^{* *}$ & 0,000 & Diterima \\
Pelaksanaan pemasaran $\rightarrow$ Omzet & $0,370^{* *}$ & 0,000 & Diterima \\
Pelaksanaan pemasaran $\rightarrow$ Keuntungan usaha & $0,334^{* *}$ & 0,000 & Diterima \\
\hline
\end{tabular}

**. Correlation is significant at the 0,01 level (2-tailed).

Adanya hubungan yang signifikan dan positif dari orientasi pasar terhadap Omzet maupun terhadap keuntungan usaha menunjukkan bahwa pembudi daya ikan harus terus meningkatkan orientasi pasar yang diindikasikan oleh pengetahuan pasar, orientasi konsumen, orientasi pesaing, koordinasi dengan tenaga kerja dan orientasi pelaksanaan pemasaran agar kinerja usaha budi daya ikan hias air tawar berupa Omzet dan keuntungan usaha di sentra produksi Jawa Barat semakin meningkat.

Hasil uji hipotesis ketiga (Ha3) menunjukkan bahwa hubungan antara indikator-indikator orientasi pasar (pengetahuan pasar, orientasi konsumen, orientasi pesaing, koordinasi dengantenaga kerja dan pelaksanaan pemasaran) dengan Omzet usaha diterima. Artinya indikator-indikator orientasi pasar (pengetahuan pasar, oriretasi konsumen, orientasi pesaing, koordinasi dengan tenaga kerja dan pelaksanaan pemasaran) memiliki hubungan yang signifikan dengan Omzet usaha pada taraf nyata $10 \%$, dengan nilai rs (rank Spearman) positif.
Hasil uji hipotesis keempat (Ha4) menunjukkan bahwa hubungan antara indikator-indikator orientasi pasar (pengetahuan pasar, orientasi konsumen, orientasi pesaing, koordinasi dengan tenaga kerja dan pelaksanaan pemasaran) dengan keuntungan usaha diterima. Artinya indikator-indikator orientasi pasar (pengetahuan pasar, orientasi konsumen, orientasi pesaing, koordinasi dengan tenaga kerja dan pelaksanaan pemasaran) memiliki hubungan yang signifikan dengan keuntungan usaha pada taraf nyata $10 \%$, dengan nilai rs (rank Spearman) positif.

Hasil uji hipotesis ketiga (Ha3) dan hipotesis keempat (Ha4) mengindikasikan bahwa semakin tinggi pengetahuan pasar, orientasi konsumen, orientasi pesaing, koordinasi dengan tenaga kerja dan pelaksanaan pemasaran yang dilakukan pembudi daya ikan, maka Omzet usaha dan keuntungan usaha budi daya ikan hias air tawar akan semakin meningkat. 


\section{Implikasi Manajerial}

Pembudi daya ikan hias air tawar di sentra produksi Jawa Barat umumnya tidak memiliki pendidikan formal yang terkait dengan bidang usaha budi daya ikan secara teknis maupun bisnis. Namun, terbukti bahwa tingkat orientasi pasar pembudi daya ikan terkategori tinggi serta berpengaruh signifikan dan positif terhadap kinerja usaha. Oleh karena itu, Dinas-dinas terkait di tingkat kabupaten/kota di provinsi Jawa Barat yang memiliki kewenangan dalam mendukung pengembangan usaha budi daya ikan hias air tawar seperti Dinas Peternakan dan Perikanan, Dinas Tanaman Pangan Pertanian dan Perikanan, Dinas Koperasi UKM Perindustrian dan Perdagangan, perlu membantu melakukan peningkatan kompetensi bidang usaha khususnya bidang pemasaran para pembudi daya ikan hias air tawar antara lain berupa pelatihan dan bimbingan teknis pemasaran dengan materi yang up to date dan dilaksanakan secara berkesinambungan terutama materi komunikasi, negosiasi bisnis dan strategi pemasaran ekspor sesuai era industri saat ini agar pembudi daya ikan memiliki kepercayaan diri yang semakin tinggi, lebih memahami kondisi dan dinamika pasar ekspor sebagai target pasar utama, serta memiliki kemampuan mengelola pemasaran yang lebih baik di era industri yang semakin kompetitif dengan perilaku dan selera konsumen yang terus berubah. Perlu pula dilakukan program khusus pelaksanaan dan penguatan kemampuan pemasaran mandiri para pembudi daya ikan hias melalui kelembagaan usaha koperasi ikan hias air tawar serta kerjasama dengan investor untuk pengembangan pemasaran yang memungkinkan pembudi daya ikan mampu melakukan pengembangkan produk, meningkatkan akses modal dan akses pasar sehingga loyalitas pelanggan dapat terjaga, volume pemasaran dan wilayah pasar bertambah serta ada peningkatan bargaining position mereka di pasar ekspor ikan hias.

\section{KESIMPULAN DAN SARAN}

\section{Kesimpulan}

Hasil penelitian diketahui bahwa tingkat orientasipasar pembudi daya ikan hias di sentra produksi Jawa Barat terkategori tinggi sehingga mampu menghasilkan modus omzet usaha Rp216.000.000 dan modus keuntungan usaha Rp33.971.333 pada tahun 2018.
Orientasi pasar, demikian pula masing-masing indikator orientasi pasar (pengetahuan pasar, orientasi konsumen, orientasi pesaing, koordinasi dengan tenaga kerja dan pelaksanaan pemasaran) memiliki hubungan yang signifikan dan positif terhadap kinerja usaha (omzet maupun keuntungan usaha). Hal ini berbeda dengan penelitian terdahulu oleh Osmani dan Hossain (2016) yang menunjukkan bahwa tingkat orientasi pasar petani kecil di Banglades tergolong sedang. Namun demikian, hasil penelitian ini sejalan dan memperkuat temuan penelitian terdahulu oleh Jaworski dan Kohli (1990), Shergill dan Nargundkar (2005), Umar (2014), Saeed dan Aimin (2015), Jayaningrum dan Sanawiri (2018) yang menunjukkan bahwa orientasi pasar berpengaruh positif signifikan terhadap kinerja usaha. Indikator orientasi pasar tertinggi pada penelitian ini adalah orientasi konsumen, hal ini memperkuat temuan Purwasari dan Suprapto (2014) bahwa orientasi pasar berpengaruh signifikan terhadap kinerja usaha dan bahwa perusahan skala kecil lebih unggul dalam hal orientasi kepada konsumen.

\section{Saran}

Penelitian selanjutnya dapat mengkaji kombinasi orientasi pasar dengan variabel-variabel lain yang diduga memengaruhi kinerja usaha budi daya ikan hias air tawar. Misalnya modal sosial dan orientasi pembelajaran pembudi daya ikan dengan menggunakan alat analisis multivariat. Hal ini bertujuan dapat disusun model alternatif untuk pemecahan masalah yang berhubungan dengan peningkatan kinerja usaha budi daya ikan hias air tawar di Jawa Barat.

\section{UCAPAN TERIMAKASIH}

Ucapan terimakasih disampaikan kepada Pimpinan Departemen Agribisnis-Fakultas Ekonomi dan Manajemen-IPB serta pimpinan Sekolah Bisnis IPB yang telah memberikan izin untuk menyelesaikan studi program Doktor kepada author, demikian pula kepada pengelola Project NICHE (The Netherlands Initiative for Capacity Development in Higher Education) yang telah memberikan dukungan dana pendidikan program Doktor; kemudian kepada Kementerian Riset, Teknologi dan Pendidikan Tinggi yang telah memberikan dukungan dana penelitian. 


\section{DAFTAR PUSTAKA}

[BPS] Badan Pusat Statistik Kota Depok. 2016. Kota Depok Dalam Angka 2016. Depok: BPS.

[DISKOPUKMPERINDAG] Dinas Koperasi UKM Perindustrian dan Perdagangan Kabupaten Bogor. 2015. Kajian Pengembangan Komoditas Ekspor Ikan Hias Air Tawar Kabupaten Bogor. Bogor: PEMKAB Bogor.

[DISNAKKAN] Dinas Peternakan dan Perikanan Kabupaten Bogor. 2016. Buku Data Perikanan 2015. Bogor: PEeMKAB Bogor.

[DinasTPP]. Dinas Tanaman Pangan Pertanian dan Perikanan Kota Depok. 2014. Laporan Akhir Penyusunan Kajian Market Intelegence dan Market Informatif untuk Pasar Domestik Industri Ikan Hias Kota Depok. Depok: Dinas Tanaman Pangan Pertanian dan Perikanan Kota Depok.

[DITJEN P2HP-KKP] Direktorat Jenderal Pengolahan dan Pemasaran Hasil Perikanan Kementerian Kelautan dan Perikanan. 2013. Statistik Ekspor Hasil Perikanan Menurut Komoditi, Provinsi Dan Pelabuhan Asal Ekspor 2012. http://statistik. kkp.go.id/sidatik-dev/Publikasi/src/kpda2015. pdf. [2017 Maret 20].

[DJPB KKP] Direktorat Jenderal Perikanan Budi daya Kementerian Kelautan dan Perikanan. 2014. Laporan Tahunan Direktorat Produksi Tahun 2013. Jakarta: KKP.

Gholami, S. \& Birjandi, M. 2016. The effect of market orientation and entrepreneurial orientation on the performance of SMEs. Journal of Current Research Science (JCRS) 1: 361-369.

Halim H, Solimun D, Djumahir. 2012. Kapabilitas pemasaran sebagai mediasi pengaruh orientasi pasar, orientasi pembelajaran dan oroentasi kewirausahaan terhadap kinerja pemasaran: studi pada usaha menengah di Sulawesi tenggara. Jurnal Aplikasi Manajemen 10(3):472-484.

Hartelina. 2010. Orientasi pasar dan inovasi organisasi dalam meningkatkan pangsa pasar serta implikasinya pada profitabilitas: survei pada Usaha Kecil Menengah/UKM industri kerajinan di Kalimantan Tengah [disertasi]. Bandung: Universitas Padjadjaran Bandung.

Han JK, Kim N, Srivastava RK. 1998. Marketorientation and organizational performance: is innovation a missing link?. Journal of Marketing 62: 30-45. https://doi.org/10.1177/002224299806200403.

Jayaningrum E, Sanawiri B. 2018. Pengaruh orientasi pasar, inovasi, orientasi kewirausahaan terhadap keunggulan bersaing dan kinerja pemasaran. Jurnal Administrasi Bisnis (JAB) 54 (1): 149158.

Jaworski BJ, Kohli AK. 1990. Market orientation: the construct, research proposition and managerial implication. Journal of Marketing 54: 1-18. https://doi.org/10.1177/002224299005400201.

Kementerian Kelautan dan Perikanan. 2014. Laporan Tahunan Direktorat Produksi Tahun 2013. Direktorat Jenderal Perikanan Budidaya, Kementerian Kelautan dan Perikanan.

Kohli AK, Jaworski BJ, Kumar A. 1993. MARKOR: A measure of market orientation. Journal of Marketing Research 30(4): 467-477. https:// doi.org/10.1177/002224379303000406.

Muttaman, Sumarwan, Tinaprilla N. 2019. Pengaruh Pengetahuan konsumen, kualitas produk dan kepercayaan konsumen terhadap loyalitas pelanggan pada pengisian angina merek Green nitrogen. Jurnal Aplikasi Manajemen dan Bisnis 5(2): 231-241. https://doi.org/10.17358/ jabm.5.2.231.

Narver JC, Slater SF. 1990. The effect of a market orientation on business profitability. Journal of Marketing 54:20-35. https://doi. org/10.1177/002224299005400403.

Osmani AG, Hossain E. 2016. Smallholder farmers' market orientation and the factors affecting it in Bangladesh. Economics Insight-Trade and challenges V(LXVIII) (3): 9-18

Purwasari M, Suprapto B. 2014. Pengaruh Orientasi pasar terhadap kinerja Café di Yogyakarta [tesis]. Yogyakarta: Universitas Atmajaya.

Raja S et al. 2014. Potential of ornamental fish culture and marketing strategies for future prospects in India. International Journal of Biosciences and Nanosciences 1(5): 119-125.

Rani P, Imanuel S, Kumar NR. 2014. Ornamental fish export from India: performance, competitiveness and deteminants. International of Fisheries and Aquatic Studies 1(4): 85-92.

Riana IG. 2010. Dampak penerapan kultur lokal tri hita karana terhadap orientasi kewirausahaan dan orientasi pasar. Jurnal Teknik Industri 13(1) : 37-44. https://doi.org/10.9744/jti.13.1.37-44.

Ruekert RW. 1992. Developing a market orientation: an organizational strategy perspective. International Journal of research in Marketing 9: 225-245. https://doi.org/10.1016/0167-8116(92)90019-H.

Saeed AA, Aimin W. 2015. Market orientation and innovation: a review of literature. International 
JournalofInnovation and Economic Development 1(1): 17-26. https://doi.org/10.18775/ijied.18497551-7020.2015.11.2002.

Shergill GS, Nargundkar R. 2005. Market orientation, marketing innovation as performance drivers: extending the paradigm. Journal of Global Marketing 19(1): 27-44. https://doi.org/10.1300/
J042v19n01_03.

Umar ZA. 2014. Peran kemampuan manajemen dan orientasi pasar sebagai mediasi pengaruh orientasi kewirausahaan terhadap kinerja bisnis: studi pada industri kecil dan menengah pangan di Gorontalo [disertasi]. Gorontalo: Universitas Negeri Gorontalo. 